\title{
Cost of Cultivation and Economic Returns Analysis of Cashewnut in West Garo Hills of Meghalaya
}

\author{
Lakshmi Dhar Hatai
}

Department of Basic Science \& Humanities, College of Home Science, Central Agricultural University, Tura, Meghalaya, India Corresponding author: lakshmidharhatai@gmail.com

\begin{abstract}
Adoption of new technology and sustainable utilization of resources can help cashewnut growers in minimizing the cost of production. New paradigm and challenges are needed for cashewnut growers of Meghalaya in solving the problem like recurrent price fluctuation, high inputs costs, marketing, storage and transportation cost, non-availability of adequate storage facilities, post harvest losses and lack of competitive marketing system. Cashewnut production plays a pivot role in fostering and sustaining the tempo of rural development in the study area. Meghalaya has become very popular in organic farming which gives very good returns from the Garo Hills region as well as export market. As the low input intensity of agriculture in Meghalaya and makes cashewnut ideally suited for organic produce is expected to boost up in near future due to the steps initiated under National Horticulture Mission for doubling the farm incomes. The study signifies and confirms the economics of cashewnut production for sustainable resource management, enhanced income generations and enlarged employment opportunities on a long term prospective.
\end{abstract}

Keywords: Cost of Cultivation, Economic Returns, Cashewnut, Meghalaya

Meghalaya in the North-East region is endowed with diverse agro-climatic conditions, rich genetic diversities, vast hydrological resources and pollution free environment that offer a great scope to develop agro-ecosystem a specific technological intervention for diversification of the Agriculture and allied activities viz. horticulture, animal husbandry and fisheries etc. The state displays a distinct ethnic, socio-cultural and geographical identity. Cashewnut cultivation is a technically feasible, financially viable and bankable activity in the areas identified suitable for it based on agro-climatic conditions. West Garo Hills District has an area of 4899 ha. under cashewnut with an estimated annual production of about 12603 Metric tonnes of raw cashew nut (2012-13). Cashew (Anacardium occidentale), a native of Brazil, was introduced in India during the later half of the Sixteenth Century for the purpose of afforestation and soil conservation. Cashew is one of the important nuts grown in the world with a production of 37.20 lakh tonnes from a harvested area of 40.97 lakh ha. (FAO, 2008). Commercial cultivation of cashew is taken up in eight states of our country mainly in west and eastern coast viz., Andhra Pradesh, Goa, Karnataka, Kerala, Maharashtra, Orissa, Tamil Nadu and West Bengal. In addition, cashew is also grown in few pockets of Assam, Chattisgarh, Gujarat, Meghalaya, Nagaland and Tripura. India has an area of 1027 thousand ha. under cashew with an estimated annual production of about 725.42 thousand MT of raw cashew nut (2014-15). India is the second largest producer and exporter of cashew in the world next only to Vietnam. It is the second largest consumer of cashew and also the biggest processor with highest acreage under the crop. The current cashew production of the country accounts for $18.68 \%$ of the global production.

Stagnating productivity, rising costs, declining farm incomes, and high price volatility of agricommodities, are making farming un-remunerative and risky. A significant revolution in food habits is 
encouraging diversification towards high - value commodities, post-harvest processing and value addition of agricultural produce. To raise income, employment, profitability, food security, global competitiveness and social welfare, a holistic approach with emphasis in cashewnut production has become imminent. Farmers' income can be increased not just by increasing productivity but also through efficient and effective cashewnut production as well as value addition. The difference between price paid by consumers for value added products and farmers realization has been increasing rapidly. Lack of backward linkages between farmers, processors and longer chain intermediaries has resulted in lack of adequate economic benefits to farmers. Cashewnut has a potential to generate more local jobs, better income and services. In-spite of various initiatives and technological options made available through horticulture department and extensive $R \& D$ efforts is yet not reached to the people of West Garo Hills of Meghalaya, for which it was meant more specifically in developing the value chain of the cashewnut and value addition for better marketing. Apart from this, emphasis is needed for specific end products and commercializing them which have market potential through technological application at local level and producing value added products. Up-gradation in the value chain of cashewnut can improve the national export potential as well as remunerative return to the farmers motivating them to scale up the farming. So, the post-harvest management, quality management and value added products in cashewnut as per the market demand can bring in growth in the agricultural return to the farmers.

Adoption of new technology and sustainable utilization of resources can help cashewnut growers in minimizing the cost of production. New paradigm and challenges are needed for cashewnut growers of Meghalaya in solving the problem like recurrent price fluctuation, high marketing, storage and transportation cost, non-availability of adequate storage facilities, post harvest losses and lack of competitive marketing system. However, the magnitude of post harvest losses in cashewnut is quite high which has been a matter of prime concern for the policy makers and researchers. Post harvest loss due to mishandling, lack of wash/ cleaning, immature harvesting etc. have been constraints for the farmers in the way of getting a good price of the produces. Cashewnut production plays a pivot role in fostering and sustaining the tempo of rural development in the study area. Meghalaya has become very popular in organic farming which gives very good returns from the Garo Hills region as well as export market. As the low input intensity of agriculture in Meghalaya and makes cashewnut ideally suited for organic produce is expected to boost up in near future due to the steps initiated under National Horticulture Mission. The study signifies and confirms the economics of cashewnut production for sustainable resource management, enhanced income generations and enlarged employment opportunities on a long term prospective.

\section{Nature, Sources and Sampling of Data}

The present study was undertaken with the sample of 120 Cashewnut growers comprising of 60 small (1-2 ha.), 40 medium (2-4 ha.) and 20 large (> 4 ha.) farmers of their cashewnut cultivated area from eight villages of Selsella and Dadenggiri CD Blocks of West Garo Hills districts of Meghalaya through stratified random sampling method. The West Garo Hills District in Meghalaya was selected purposively due to concentration of cashewnut growers in these districts as compared to other district. The data were collected from the sample cashewnut growers through personal interview method with the help of a specially designed schedule covering all aspects. Data pertaining to the agricultural year 2016-17 was considered with specific objectives. The project covers one of the horticultural crop i.e. cashewnut with value addition in selected locations. The selected district is namely West Garo Hills, which is having required quantum of cashewnut production. Two blocks from the district was selected for the implementation of the research project. The existing production potential can be suitably utilised for value addition and production of value added products of cashewnut.

\section{Analytical Techniques for Costs and Returns}

To work out the costs and returns of Cashew production, cost concept recommended by the Commission for Agricultural Costs and Prices (CACP) was used viz., Cost $\mathrm{A}_{1}$, Cost $\mathrm{A}_{2}$, Cost $\mathrm{B}_{1^{\prime}}$ Cost $B_{2}$, Cost $C_{1}$, and Cost $C_{2}$ was used. 
$\square$ Cost $\mathbf{A}_{1}$ : Value of hired human labour + Attached labour, Value of owned and hired bullock labour + charges on owned and hired machinery + Value of seed (both farm produced and purchased) + Value of owned and purchased manures + value of fertilizers + value of plant protection chemicals used + depreciations + repairs and maintenance of farm machinery and farm implements and farm buildings + land revenue, cesses + interest on working capital.

Cost $A_{2}:$ Cost $A_{1}+$ Rent paid on leased in land.

$\square$ Cost $B_{1}$ : Cost $A_{2}+$ Imputed interest on owned fixed capital excluding land.

$\square$ Cost $B_{2}$ : Cost $B_{1}+$ Rental value of owned land (less land revenue) and Rent paid for leased in land.

$\square$ Cost $C_{1}$ : Cost $B_{1}+$ Imputed value of family labour

$\square$ Cost $C_{2}$ : Cost $B_{2}+$ Imputed value of family labour

Farm Business Measures: The farm business measures are Gross Income, Net Income, Farm Business Income, Family Labour Income and Farm Investment Income. These measures were used in the study to arrive at the benefits to the Cashes farmers. These are calculated using the standard formulae as follows:

Gross Income $=$ Value of total output (Main + by products)

Farm Business Income $=$ Gross Return - Cost A1.

Owned Farm Business Income $=$ Gross Return - Cost A2.

Family Labour Income = Gross Return - Cost B2

Net Income $=$ Gross Return - Cost C2 .

$\square$ Farm Investment Income $=$ Net Income + Imputed rental value of owned land + Interest on fixed capital.

Benefit-Cost Ratio (BCR): Benefit-cost ratio (BCR) is the ratio derived by dividing the present value of benefits, by present value of cost. This ratio measures the return or benefit per units of cost or investment. While ranking the projects, choose the projects having B-C ratio of more than one. Finally, the given project is opted for implementation, among alternatives based on the highest $\mathrm{B}-\mathrm{C}$ ratio.

$$
\text { B-C Ratio }=\frac{\sum_{t=1}^{n} \frac{B t}{(1+i)^{t}}}{\sum_{t=1}^{n} \frac{C t}{(1+i)^{t}}}
$$

Where,

$\mathrm{B}=$ Benefit received each year

$\mathrm{C}=$ Cost incurred each year

$\mathrm{t}=$ Time in years

$\mathrm{n}=$ Number in years of the project (duration)

$\mathrm{i}=$ Interest rate for discounting the cost/benefit

Net Present Worth (NPW): It is also referred as Net Present Value (NPV). It represents the present worth of incremental net benefit i.e. the income stream generated by an investment. The NPW can be calculated by taking the difference between present value of benefits and present value of costs. (NPW $=$ Discounted benefits - Discounted costs). NPW is an absolute measure, but not relative.

$$
\mathrm{NPW}=\sum_{i=1}^{N} \frac{B t-C t}{(1+i)^{t}}
$$

Where,

$\mathrm{B}=$ Benefit received each year

$\mathrm{C}=$ Cost incurred each year

$\mathrm{t}=$ Time in years

$\mathrm{n}=$ Number in years of the project duration

$\mathrm{i}=$ Interest rate for discounting the cost/benefit

\section{Area and Production of Raw Cashewnut}

Findings of the study revealed from Table 1, that the villages namely, Amingokgre, Adinggre Chibonggre and Daljagre of Dadenggre CD Block, and villages namely, Dabakgre, Mronggre, Rongramgre and Makbilkolgre of Selsella CD Block all the sample categories (30 - small, 20 - medium and 10 large) were under Cashewnut cultivation. It was observed that on an average Cashewnut cultivated area (ha) in case of small, medium and large farmers of Dadenggre were 0.67 ha., 2.35 ha, 4.2 ha. respectively. It was seen that average production of raw cashewnut in case of small, medium, and large farmers were $2.43 q, 6.05 q$ and $8.7 q$ respectively. 
Table 1: Area and Production of Raw Cashewnut in Different sample villages of study

\begin{tabular}{ccccccc}
\hline & \multicolumn{3}{c}{ Dadenggre Block } & \multicolumn{3}{c}{ Selsella Block } \\
\cline { 2 - 7 } & Small Farmers & $\begin{array}{c}\text { Medium } \\
\text { Farmers }\end{array}$ & Large Farmers & $\begin{array}{c}\text { Small } \\
\text { Farmers }\end{array}$ & $\begin{array}{c}\text { Medium } \\
\text { Farmers }\end{array}$ & $\begin{array}{c}\text { Large } \\
\text { Farmers }\end{array}$ \\
\hline $\begin{array}{c}\text { Average Cashewnut Plantation } \\
\text { Area (Ha) }\end{array}$ & 0.67 & 2.35 & 4.2 & 0.85 & 2.40 & 4.3 \\
$\begin{array}{c}\text { Average Production of Raw } \\
\text { Cashewnut (Qtl) } \\
\text { Size of Sample (n) }\end{array}$ & 2.43 & 6.05 & 8.7 & 2.68 & 4.15 & 8.2 \\
\hline
\end{tabular}

Source: Own Field Survey, (2017-18).

In case of Selsella Block, the average Cashewnut cultivated area (ha) for small, medium and large farmers were 0.85 ha., 2.4 ha, 4.3 ha. Respectively; where as the average production of raw cashewnut in case of small, medium, and large farmers were $2.68 \mathrm{q}, 4.15 \mathrm{q}$ and $8.2 \mathrm{q}$ respectively.

\section{Cost of Cultivation of Cashewnut}

The cost concept analysis in cashewnut cultivation shows that the cashewnut orchard is capital intensive in its initial stage and labour intensive later which shows its cost increased gradually from year to year. The cost of cultivation of cashewnut is presented in the Table 2, and share of cost items in total cost is presented in Fig. 1, since the fruit bearing of cashewnut started in fifth year of cultivation, therefore for better understanding the cost of cultivation of cashewnut was added upto fourth year of cultivation.

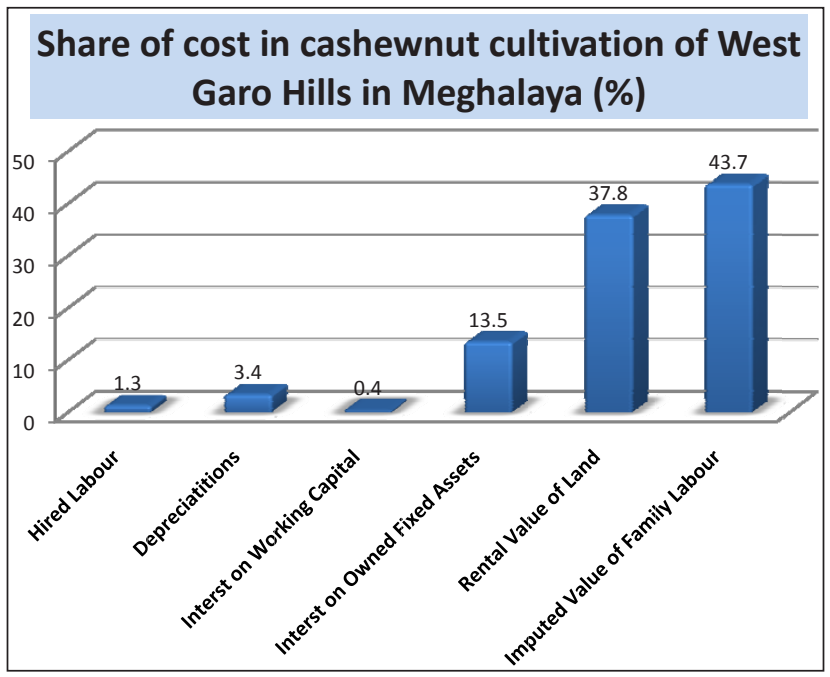

Fig. 1: Share of cost in total cost of cashewnut cultivation in West Garo Hills of Meghalaya

During the period of first fourth year of cultivation, the Cost $\mathrm{C}_{2}$ (Comprehensive Cost) decreases from
₹ $96,620.50$ per ha to $₹ 15,926.27$ per ha in the year of fifth year in West Garo Hills district. But the cost was found to increased gradually from ₹ 17137.42 per ha in the sixth year to ₹ 19861.01 per ha of the tenth year of cashewnut cultivation. The Cost $\mathrm{C}_{2}$ was worked out to be higher in the first fourth year of cultivation because of establishment cost which is capital intensive, and the later on its cost was gradually increase from year to year due to labour intensive.

\section{Economic Returns of Cashewnut}

The economic returns from Cashewnut cultivation is presented in the Table 3. The yield of Cashewnut was found to increase gradually from $5.72 \mathrm{q} / \mathrm{ha}$ in the year of fifth year to $20.78 \mathrm{q} /$ ha in tenth year of Cashewnut cultivation. The Gross Farm Income (GFI) was found to increasing from ₹ 34,321.43 per ha in the fifth year to ₹ $1,24,685.20$ per ha in the year of tenth year. The net farm income was found ₹ 104824.19 per ha in the tenth year of Cashewnut cultivation. The net returns including family labour was found to be positive from $7^{\text {th }}$ year ( $₹ 5368.92$ per ha) onwards in which the cost incurred in the previous year was covered up and profit started. The returns excluding family labour was worked out to be positive from fifth year (₹ 14416.24 per ha) and Farm business income was estimated to be positive from fifth year onwards in West Garo Hills district (₹ 2623.84 per ha). The farm investment income was worked out to be positive from sixth year (₹ 21821.79) per ha. of cashewnut cultivation. The Net present value (NPV) was estimated to be positive from eighth year ( $₹ 17017.48$ per ha) onwards. The Benefit cost ratio (BCR) over total cost was found to be greater than one from fifth year (2.15) onward in the study area. Moreover, the economic return analysis shows that cashewnut 
Table 2: Cost of Cultivation of Cashewnut in West Garo Hills of Meghalaya (₹/ha)

\begin{tabular}{|c|c|c|c|c|c|c|c|}
\hline Cost Items / Particulars & $1^{\text {st }}$ to $4^{\text {th }}$ year & $5^{\text {th }}$ year & $6^{\text {th }}$ year & $7^{\text {th }}$ year & $8^{\text {th }}$ year & $9^{\text {th }}$ year & $10^{\text {th }}$ year \\
\hline Establishment Cost & $\begin{array}{c}21842.45 \\
(25.21)\end{array}$ & - & - & - & - & - & - \\
\hline Hired Labour & $3272.08(3.78)$ & $675.66(4.24)$ & $632.42(3.69)$ & $580.74(3.22)$ & $458.12(2.41)$ & $372.50(1.90)$ & $255.40(1.28)$ \\
\hline Depreciation & $2685.62(3.10)$ & $671.40(4.21)$ & $671.40(3.91)$ & $671.40(3.73)$ & $671.40(3.53)$ & $671.40(3.42)$ & $671.40(3.38)$ \\
\hline Land revenue & - & - & - & - & - & - & - \\
\hline Sub total & $\begin{array}{c}27800.15 \\
(32.09)\end{array}$ & $\begin{array}{c}1347.06 \\
(8.45)\end{array}$ & $1303.82(7.60)$ & $\begin{array}{c}1252.14 \\
(6.95)\end{array}$ & $\begin{array}{c}1129.52 \\
(5.94)\end{array}$ & $\begin{array}{c}1043.90 \\
(5.32)\end{array}$ & $\begin{array}{l}926.80 \\
(4.66)\end{array}$ \\
\hline $\begin{array}{l}\text { Interest on working } \\
\text { capital @ } 8.75 \%\end{array}$ & $2432.51(2.80)$ & $117.87(0.74)$ & $114.08(0.66)$ & $109.56(0.60)$ & $98.83(0.52)$ & $91.34(0.46)$ & $81.09(0.40)$ \\
\hline Cost $\mathrm{A}_{1}$ & $\begin{array}{c}30232.66 \\
(34.90)\end{array}$ & $\begin{array}{c}1464.93 \\
(9.20)\end{array}$ & $1417.90(8.27)$ & $\begin{array}{c}1361.70 \\
(7.57)\end{array}$ & $\begin{array}{c}1228.35 \\
(6.46)\end{array}$ & $\begin{array}{c}1135.24 \\
(5.79)\end{array}$ & $\begin{array}{c}1007.89 \\
(5.07)\end{array}$ \\
\hline $\begin{array}{c}\text { Rent paid for leased in } \\
\text { Land }\end{array}$ & - & - & - & - & - & - & - \\
\hline Cost $\mathrm{A}_{2}$ & $\begin{array}{c}30232.66 \\
(34.90)\end{array}$ & $\begin{array}{c}1464.93 \\
(9.20)\end{array}$ & $\begin{array}{c}1417.90 \\
(8.27)\end{array}$ & $\begin{array}{c}1361.70 \\
(7.57)\end{array}$ & $\begin{array}{c}1228.35 \\
(6.46)\end{array}$ & $\begin{array}{c}1135.24 \\
(5.79)\end{array}$ & $\begin{array}{c}1007.89 \\
(5.07)\end{array}$ \\
\hline $\begin{array}{l}\text { Interest on owned fixed } \\
\text { assets (excluding land) }\end{array}$ & $\begin{array}{c}10755.20 \\
(12.42)\end{array}$ & $\begin{array}{c}2688.80 \\
(16.88)\end{array}$ & $\begin{array}{r}2688.80 \\
(15.68)\end{array}$ & $\begin{array}{r}2688.80 \\
(14.94)\end{array}$ & $\begin{array}{c}2688.80 \\
(14.14)\end{array}$ & $\begin{array}{c}2688.80 \\
(13.71)\end{array}$ & $\begin{array}{r}2688.80 \\
(13.54)\end{array}$ \\
\hline Cost $\mathrm{B}_{1}$ & $\begin{array}{c}40987.85 \\
(47.32)\end{array}$ & $\begin{array}{l}4153.73 \\
(26.08)\end{array}$ & $\begin{array}{l}4106.70 \\
(23.96)\end{array}$ & $\begin{array}{l}4050.50 \\
(22.51)\end{array}$ & $\begin{array}{l}3917.15 \\
(20.60)\end{array}$ & $\begin{array}{c}3824.04 \\
(19.50)\end{array}$ & $\begin{array}{r}3696.69 \\
(18.61)\end{array}$ \\
\hline $\begin{array}{l}\text { Rental value of land less } \\
\text { land revenue + rent paid } \\
\text { for leased in }\end{array}$ & $\begin{array}{c}30000.00 \\
(34.63)\end{array}$ & $\begin{array}{r}7500.00 \\
(47.09)\end{array}$ & $\begin{array}{c}7500.00 \\
(43.76)\end{array}$ & $\begin{array}{r}7500.00 \\
(41.68)\end{array}$ & $\begin{array}{c}7500.00 \\
(39.45)\end{array}$ & $\begin{array}{c}7500.00 \\
(38.26)\end{array}$ & $\begin{array}{c}7500.00 \\
(37.76)\end{array}$ \\
\hline Cost $B_{2}$ & $\begin{array}{c}70987.85 \\
(81.95)\end{array}$ & $\begin{array}{c}11653.73 \\
(73.17)\end{array}$ & $\begin{array}{l}11606.7 \\
(67.72)\end{array}$ & $\begin{array}{c}11550.50 \\
(64.19)\end{array}$ & $\begin{array}{c}11417.15 \\
(60.06)\end{array}$ & $\begin{array}{c}11324.04 \\
(57.77)\end{array}$ & $\begin{array}{c}11196.69 \\
(56.37)\end{array}$ \\
\hline $\begin{array}{l}\text { Imputed value of family } \\
\text { labour }\end{array}$ & $\begin{array}{c}15632.65 \\
(18.04)\end{array}$ & $\begin{array}{c}4272.54 \\
(26.82)\end{array}$ & $\begin{array}{c}5530.72 \\
(32.27)\end{array}$ & $\begin{array}{l}6442.16 \\
(35.80)\end{array}$ & $\begin{array}{l}7590.02 \\
(39.93)\end{array}$ & $\begin{array}{r}8276.45 \\
(42.22)\end{array}$ & $\begin{array}{c}8664.32 \\
(43.62)\end{array}$ \\
\hline Cost $C_{1}$ & $\begin{array}{c}56620.50 \\
(65.36)\end{array}$ & $\begin{array}{r}8426.27 \\
(52.90)\end{array}$ & $\begin{array}{r}9637.42 \\
(56.24)\end{array}$ & $\begin{array}{c}10492.66 \\
(58.32)\end{array}$ & $\begin{array}{c}11507.17 \\
(60.54)\end{array}$ & $\begin{array}{c}12100.49 \\
(61.73)\end{array}$ & $\begin{array}{c}12361.01 \\
(62.24)\end{array}$ \\
\hline $\begin{array}{l}\text { Imputed value of family } \\
\text { labour }\end{array}$ & $\begin{array}{c}15632.65 \\
(18.04)\end{array}$ & $\begin{array}{l}4272.54 \\
(26.82)\end{array}$ & $\begin{array}{c}5530.72 \\
(32.27)\end{array}$ & $\begin{array}{c}6442.16 \\
(35.80)\end{array}$ & $\begin{array}{l}7590.02 \\
(39.93)\end{array}$ & $\begin{array}{c}8276.45 \\
(42.22)\end{array}$ & $\begin{array}{c}8664.32 \\
(43.62)\end{array}$ \\
\hline $\operatorname{Cost} \mathrm{C}_{2}$ & $\begin{array}{l}86620.50 \\
(100.00)\end{array}$ & $\begin{array}{l}15926.27 \\
(100.00)\end{array}$ & $\begin{array}{l}17137.42 \\
(100.00)\end{array}$ & $\begin{array}{l}17992.66 \\
(100.00)\end{array}$ & $\begin{array}{l}19007.17 \\
(100.00)\end{array}$ & $\begin{array}{l}19600.49 \\
(100.00)\end{array}$ & $\begin{array}{l}19861.01 \\
(100.00)\end{array}$ \\
\hline
\end{tabular}

Note: Figures in the parentheses are percentage to the total.

Table 3: Economic Returns Analysis of Cashewnut in West Garo Hills of Meghalaya (₹/ha)

\begin{tabular}{|c|c|c|c|c|c|c|c|}
\hline Returns & $1^{\text {st }}-4^{\text {th }}$ Year & $5^{\text {th }}$ Year & $6^{\text {th }}$ Year & $7^{\text {th }}$ Year & $8^{\text {th }}$ Year & $9^{\text {th }}$ Year & $10^{\text {th }}$ Year \\
\hline Yield (q/ha) & - & 5.72 & 7.68 & 10.45 & 14.02 & 17.15 & 20.78 \\
\hline Gross Farm Income (GFI) & - & 34321.43 & 46051.76 & 62672.58 & 84122.80 & 102880.27 & 124685.20 \\
\hline Net Farm Income (GFI- Cost $C_{2}$ ) & -86620.50 & 18395.16 & 28914.34 & 44679.92 & 65115.63 & 83279.78 & 104824.19 \\
\hline Returns including family labour & -86620.50 & -68225.34 & -39311.0 & 5368.92 & 70484.55 & 153764.33 & 258588.52 \\
\hline Returns excluding family labour & -15632.65 & 14416.24 & 54937.28 & 111167.70 & 187700.48 & 282304.30 & 398325.18 \\
\hline Farm Business Income (GFI-Cost $\left.A_{2}\right)$ & -30232.66 & 2623.84 & 47257.70 & 108568.58 & 191463.03 & 293208.06 & 416885.37 \\
\hline $\begin{array}{c}\text { Farm Investment Income } \\
\text { (Farm Business Income- Imputed Value of } \\
\text { Family labour) }\end{array}$ & -45865.30 & -17281.35 & 21821.79 & 76690.51 & 151994.94 & 245463.52 & 360476.51 \\
\hline Net Present Value (NPV) & - & -60777.60 & -40900.91 & -15008.61 & 17017.48 & 52668.74 & 91900.95 \\
\hline $\begin{array}{c}\text { Benefit Cost Ratio (BCR): Output /Input ratio } \\
\text { over Total Cost }\left(\mathrm{GFI} / \operatorname{Cost} \mathrm{C}_{2}\right)\end{array}$ & - & 2.15 & 2.68 & 3.48 & 4.42 & 5.24 & 6.27 \\
\hline
\end{tabular}


crops in West Garo Hills of Meghalaya are highly profitable and its profitability must be realized the cashew farmers of the state. From the economic returns analysis of cashewnut cultivation, it is revealed that cashewnut is profitable from fourth year and afterward it is more or less benefit upto certain period of the crop life span, so its production need to realize among the farmer community of West Garo Hills of Meghalaya.

\section{CONCLUSION}

It is evident that the economic importance of cashewnut production, it has got greater potentiality in generative income and employment at farm level. It was observed that increase in farm size is accompanied by higher productivity and remunerative price fetched by large farmers as compared to other categories of cashewnut growers. The highest benefit cost ratio was achieved by the large farms because of judicious expenditure in cashewnut production and obtaining a sizeable amount of returns. In the West Garo Hills, cashewnut cultivation needs application of modern technology and proper management practices for better production and marketing. The study highlighted that the prospect of cashewnut production in Meghalaya is bright as the trend of other traditional crop production in the potential areas is quite encouraging for the organic cashew farming. There is enough scope of enhancing organic produce of cashewnut. Based upon the results and findings of the study following conclusions and policy implication can be suggested for improving cashewnut production in the study area i.e. West Garo Hills in Meghalaya.

Adoption of new technology and sustainable utilization of resources and farm inputs can help cashewnut growers in minimizing the cost of production.

There is training needs for modern cultivation practices on cashewnut in the study area.

New paradigm and challenges are needed for cashewnut growers of Meghalaya in solving the problem like recurrent price fluctuation, high marketing, storage and transportation cost, non-availability of adequate storage facilities, post harvest losses and lack of competitive marketing system.
Meghalaya has become very popular in organic farming which gives very good returns from the Garo Hills region as well as export market for cashew.

$\square$ Proper integration is required among different cashew growers and agencies who are engaged in production, marketing and processing (value addition) of cashew kernels for designing their future policies.

Cashewnut in Garo Hills region of Meghalaya is found to be economic feasible which can be more beneficial to reducing the costs of production through intervention of modern techniques in cultivation of the crop.

$\square$ The farmers of Garo hills region are resource poor and unable to afford the input costs as well as expenditures for marketing of cashew produces. Therefore, the financial support is necessary for the cashew farmers through inclusive credit facilities.

Cost effective agro-advisory services were need of cashew farmers at right time in right form to save the losses.

$\square$ There is an urgent need for promoting producer's cooperative and providing adequate short term credit facilities particularly in the rural areas. In order to hedge risk of cashewnut production, it is imperative to develop market intelligence services, introduction of support price and insurance scheme for cashewnut in the state.

\section{REFERENCES}

Brithal, P.S. 2010. Unlocking the potential of agriculture in North Eastern hill region of India, Indian Journal of Agricultural Economics, 65(3): 329-343.

Deorukhakar, A.C., Veerkar, P.D., Talathi, J.M. and Thakare, G.G. 1995. Yield Gap and Constraints in Technology Adoption of Cashewnut Cultivation in the Konkan Region of Maharashtra. The Cashew, 9(4): 13-17.

Government of Meghalaya, Directorate of Economics and Statistics, Shillong, Statistical Hand Book of Meghalaya, 2013.

Kumar, N. and Kapoor S. 2010. Value chain analysis of coconut in Orissa, Agricultural Economic Research Review, 23(Conf. no.): 411-418.

Nirban, A.J. and Sawant, P.A. 2000. Constraint Analysis of Cashew nut Growers. The Cashew, 14(1): 45-49.

Raikar, N.A. 1990. Investment in Production and Marketing of cashew in Karnataka. M.Sc. (Agri.) Thesis, University of Agricultural Sciences, Bangalore. 
Shibu, S., Thomas, K.J. and Thomas, E.K. 2004. Area, production and Productivity of Cashew in Kerala - A Trend Analysis. The Cashew, 18(3): 22-26. Indian Journal of Marketing, 2(3): 91-92.

Sundaravaradarajan, K.R. and Ramanathan, G. 2003. Cost, Returns and Economic Viability of Cashew Plantation in Tamil Nadu. Agricultural Situation in India, 59(11): 709-715.
Yadukumar, N., Swamy, K.R.M. and late Bhaskara Rao, E.V.V. 2003. Projection on Economics of Cashew Plantations. The Cashew, 17(3): 6-16. 
